\title{
XXII. On the determination of chemical affinity in terms of electromotive force.-Part IX
}

\section{C.R. Alder Wright D.Sc. F.R.S. \& C. Thompson F.C.S.}

To cite this article: C.R. Alder Wright D.Sc. F.R.S. \& C. Thompson F.C.S. (1885) XXII. On the determination of chemical affinity in terms of electromotive force.-Part IX, Philosophical Magazine Series 5, 19:118, 197-214, DOI: 10.1080/14786448508627664

To link to this article: http://dx.doi.org/10.1080/14786448508627664

曲 Published online: 29 Apr 2009.

Submit your article to this journal $\sqsubset \pi$

Џ Article views: 2

Q View related articles $\square$ 


\section{[ 197 ]}

XXII. On the Determination of Chemical Affinity in terms of Electromotive Force.-Part IX. By C. R. ALDER Wright, D.Sc. (Lond.), F.R.S., Lecturer on Chemistry and Plyysics, and C. Thompson, F.C.S., Demonstrator of Chemistry, in St. Mary's Hospital Medical School*.

[Concluded from p. 124.]

D. Voltaic and Thermovoltaic Constants of Metals immersed in Solutions of their Acetates.

\section{Copper.}

194. A NUMBER of cells were set up with amalgamatedA zinc and electro-copper plates immersed in solutions of their respective acetates, the constant molecular strength being $\cdot 25 \mathrm{M}\left(\mathrm{C}_{2} \mathrm{H}_{3} \mathrm{O}_{2}\right)_{2} \mathrm{H}_{2} \mathrm{O}^{*}$. The following values were obtained :-

\begin{tabular}{|c|c|c|c|}
\hline nim. & & & \\
\hline $\operatorname{Iin}$ & & . & \\
\hline verage $\cdot$ & & & \\
\hline
\end{tabular}

Julius Thomsen's thermochemical data lead to the values $\mathrm{Zn}, \mathrm{O}, 2 \mathrm{C}_{2} \mathrm{H}_{4} \mathrm{O}_{2} \mathrm{aq} .=100710$, and $\mathrm{Cu}, \mathrm{O}, 2 \mathrm{C}_{2} \mathrm{H}_{4} \mathrm{O}_{2} \mathrm{aq} .=50340$; whence $\mathrm{E}_{\mathrm{H}}=1 \cdot 111$, corresponding with 50370 grammedegrees. Hence $\mathrm{E}-\mathrm{E}_{\mathrm{H}}=-.020$ for electro-copper in contact with copper-acetate solution of strength $\cdot 25 \mathrm{Cu}\left(\mathrm{C}_{2} \mathrm{H}_{3} \mathrm{O}_{2}\right)_{2}$ $100 \mathrm{H}_{2} \mathrm{O}$.

\section{Lead.}

195. Two series of cells set up with electro-lead opposed to amalgamated zinc and electro copper respectively, with acetate solutions uniformly of strength $25 \mathrm{M}\left(\mathrm{C}_{2} \mathrm{H}_{3} \mathrm{O}_{2}\right)_{2} 100 \mathrm{H}_{2} \mathrm{O}$, gave the following results ; the differences observed between the values obtained for different cells set up in the same way being notably greater than with most of the other combinations examined :-

\begin{tabular}{|c|c|c|}
\hline & Zinc-Lead. & Lead-Copper. \\
\hline Maximum .............. & 616 & .503 \\
\hline Minimum ................ & .587 & $\cdot 471$ \\
\hline Average $\ldots \ldots \ldots \ldots . . . .$. & 608 & $\cdot 485$ \\
\hline Probable error ......... & \pm .0048 & $\pm \cdot 0044$ \\
\hline
\end{tabular}

* The acetate solutions employed were prepared by dissolving the freshly-precipitated, well-washed carbonates of the metals in boiling dilute acetic acid somewhat stronger than that required, filtering alter cooling, and diluting to the proper extent. 
198 Messrs. Wright and Thompson on the Determination of

From these average values the following valuations result for the voltaic constant for lead in acetate solution of strength $.25 \mathrm{~Pb}\left(\mathrm{C}_{2} \mathrm{H}_{3} \mathrm{O}_{2}\right)_{2} 100 \mathrm{H}_{2} \mathrm{O}$ :-

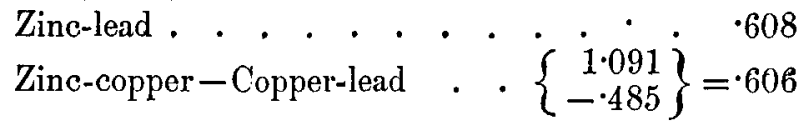

$$
\begin{aligned}
& \text { Mean . . . . } . \overline{607}
\end{aligned}
$$

Hence, since Thomsen finds that $\mathrm{Pb}, \mathrm{O}, 2 \mathrm{C}_{2} \mathrm{H}_{4} \mathrm{O}_{2}$ aq. $=$ 65770 , the value of $\mathrm{E}_{\mathrm{H}}$ is $\cdot 770$, corresponding with 34940 gramme-degrees, whence

$$
\mathrm{E}-\mathrm{E}_{\mathrm{H}}=-\cdot 163
$$

i. e. the thermovoltaic constant for lead in acetate solution is negative, and of nearly the same magnitude as in nitrate solution, or in contact with lead sulphate suspended in zinc or cadmium-sulphate solution of corresponding strength, $.25 \mathrm{PbX} 100 \mathrm{H}_{2} \mathrm{O}$. In consequence the actual E.M.F. of a lead-copper-acetate cell exceeds that due to the net chemical change taking place therein, just as in lead-copper-sulphate and lead-copper-nitrate cells.

Some observations were made on the rate of depreciation in E.M.F. with increasing current-density in zinc-lead-acetate cells, with the result of showing that the average rate of fall is indicated by a curve lying between the analogous curves obtained with zinc-silver-sulphate and iron-copper-sulphate cells ( $\$ 130$ and 176$)$, being below the former and above the latter, which, as already shown, overlie the analogous curves obtained with zinc-copper-sulphate and zinc-cadmium-sulphate cells. It is remarkable, in this connection, that the thermovoltaic constants for the metals silver, lead, iron, copper, and cadmium in these solutions respectively follow in the same order as regards numerical magnitude, though not as regards sign:-

$\begin{array}{ll}\text { Silver (in sulphate solution) } & \cdot \quad-\quad-351 \\ \text { Lead (in acetate solution) } & \cdot \dot{-} \cdot 163 \\ \text { Iron (in sulphate solution) } & +\cdot 113 \text { to }+\cdot 148 \\ \text { Copper (in sulphate solution) } & +\cdot 009 \\ \text { Cadmium (in sulphate solution) } & +\cdot 005 \text { to }-010\end{array}$

\section{Silver.}

196. The following values were obtained with cells containing electro-silver immersed in saturated silver-acetate solution opposed to amalgamated zinc and electro-copper immersed in their respective acetate solutions, the constant strength being $.057 \mathrm{M}\left(\mathrm{C}_{2} \mathrm{H}_{3} \mathrm{O}_{2}\right)_{2} 100 \mathrm{H}_{2} \mathrm{O}:-$ 


\begin{tabular}{|c|c|c|}
\hline & Zinc-Silver. & Copper-Silver. \\
\hline Maximum ............... & 1.501 & $\cdot 404$ \\
\hline Minimum .................. & $1 \cdot 486$ & $\cdot 389$ \\
\hline Average .................... & $1 \cdot 490$ & 397 \\
\hline Probable error .......... & $\pm \cdot 0024$ & $\pm \cdot 0021$ \\
\hline
\end{tabular}

From these figures the following concordant valuations are deduced for the voltaic constant of electro-silver immersed in saturated silver-acetate solution :-

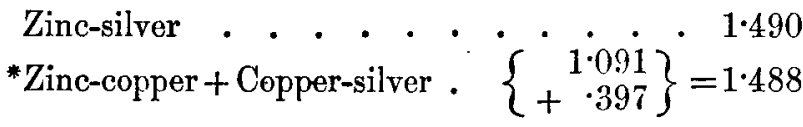

$$
\begin{aligned}
& \text { Mean . . . } \overline{1 \cdot 489}
\end{aligned}
$$

The heat of formation of silver acetate not being known, the value of $\mathrm{E}_{\mathrm{H}}$ cannot be calculated. Admitting that this value is the same as in the case of nitrate cells of the same molecular solution-strength, viz. near to $1 \cdot 890$, the value of $\mathrm{E}-\mathrm{E}_{\mathrm{H}}$ would be $-\cdot 401$; whence it is at least evident that the thermovoltaic constant for electro-silver in acetate solution is a large negative quantity, comparable in magnitude with the corresponding constants found for sulphate and nitrate solutions.

It is noteworthy that the E.M.F. of lead-silver-acetate cells deduced from the foregoing experiments is $1 \cdot 489-\cdot 607=\cdot 882$ volt. On setting up a number of such cells, however, fluctuating and inconstant figures were obtained, usually averaging during the first half-hour after setting up values from 02 to .12 volt below this amount; these cells therefore resembled in this respect the lead-copper-chloride cells abore described $(\S 184)$.

\section{E. Voltaic and Thermoroltaic Constants of Metals immersed in Solutions of their Bromides.}

197. The experiments above described indicate that the sign and magnitnde of the thermovoltaic constant for a given metal does not vary widely, whether the metal be in contact with its sulphate, nitrate, or acetate, whereas the values obtained under these circumstances are often considerably different from those obtained when in contact with its chloride. In order to

* Assumed to be the same as the value found for solution-strength $225 \mathrm{M}\left(\mathrm{C}_{2} \mathrm{H}_{3} \mathrm{O}_{2}\right)_{2} 100 \mathrm{H}_{2} \mathrm{O}$. 
trace out whether the different halogen salts exhibit analogy with these oxygen-acid salts, or whether they differ materially amongst themselves, a number of cells were examined containing various metals immersed in solutions of their respective bromides of constant streng th $\cdot 25 \mathrm{MBr}_{2} 100 \mathrm{H}_{2} \mathrm{O}$, or in magmas of their bromides immersed in zinc-bromide solution of this strength (saving in the case of lead bromide, where the sparing solubility necessitated the use of weaker solutions).

\section{Cadmium.}

The following values were obtained with zinc-cadmiumbromide cells :-

$$
\begin{aligned}
& \text { Maximum . . . . . } \cdot 319 \\
& \text { Minimum . . . . } 311 \\
& \text { Average . . . . . . } 315 \\
& \text { Probable error . . . . } \pm 0014
\end{aligned}
$$

Julius Thomsen finds the values $\mathrm{Zn}, \mathrm{Br}_{2}$ aq. $=90960$, and $\mathrm{Cd}, \mathrm{Br}_{2}$ aq. $=75640$; whence $\mathrm{E}_{\mathrm{H}}=\cdot 338$, corresponding with 15320 gramme-degrees. Hence

$$
\mathrm{E}-\mathrm{E}_{\mathrm{H}}=-\cdot 023 \text {; }
$$

that is, the thermovoltaic constant for electro-cadmium in bromide solution of strength $\cdot 25 \mathrm{CdBr}_{2} 100 \mathrm{H}_{2} \mathrm{O}$ is a small negative quantity, not quite so large numerically as that for the corresponding chloride solntion (viz. - $\cdot 036$ ).

\section{Silver.}

198. The following values were obtained with cells set up with amalgamated zinc opposed to electro-silver immersed in a magma of freshly precipitated well-washed silver bromide suspended in zinc-bromide solution, the solution-strength throughout being $\cdot 25 \mathrm{ZnBr}_{2} 100 \mathrm{H}_{2} \mathrm{O}$.

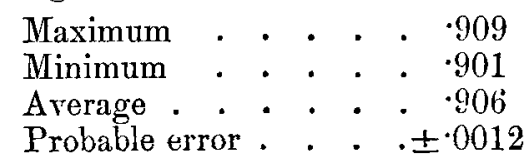

Julius Thomsen finds $\mathrm{Ag}_{2}, \mathrm{Br}_{2}=45400$; whence $\mathrm{E}_{\mathrm{H}}=1 \cdot 005$, corresponding with 45560 gramme-degrees. Hence

$$
\mathrm{E}-\mathrm{E}_{\mathrm{H}}=-\cdot 099 \text {; }
$$

that is, the thermoroltaic constant for silver in contact with silver bromide suspended in zine-bromide solution is a notable negative quantity, slightly less numerically than the corresponding value for silver chloride suspended in equally strong zinc-chloride solution (viz. - 112). 


\section{Lead.}

199. Two sets of cells were examined containing electrolead immersed in saturated solution of lead bromide of strength $\cdot 037 \mathrm{PbBr}_{2} 100 \mathrm{H}_{2} \mathrm{O}$ opposed to amalgamated zinc and electrocadmium immersed in their respective bromide solutions of the same strength. The following values were obtained :-

\begin{tabular}{|c|c|c|}
\hline & Zinc-Lead. & Cadmium-Lead. \\
\hline Maximum ............... & .575 & 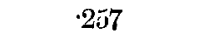 \\
\hline Minimum .................. & .567 & $\cdot 255$ \\
\hline Average ................... & $\cdot 571$ & $\cdot 256$ \\
\hline Probable error ......... & \pm .0014 & $\pm \cdot 0001$ \\
\hline
\end{tabular}

These figures lead to the following valuations for the voltaic constant of lead in saturated lead-bromide solution :-

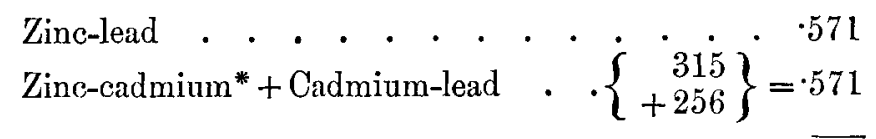

$$
\text { Mean . . . } 5 \overline{571}
$$

Julius Thomsen finds $\mathrm{Pb}, \mathrm{Br}_{2}$ aq. $=54410$; whence $\mathrm{E}_{\mathrm{H}}=\cdot 806$, corresponding with 36550 gramme-degrees. Hence

$$
\mathrm{E}-\mathrm{E}_{\mathrm{H}}=-\cdot 235 \text {; }
$$

$i$. e. the thermovoltaic constant for electro-lead in saturated lead-bromide solution is a large negative quantity, slightly greater numerically than that for lead in saturated leadchloride solution, viz. -2222 .

\section{Mercury.}

200. When mercuric-bromide solution is agitated with metallic mercury, mercurous bromide is rapidly formed, so that in a very short time practically all mercury and bromine are removed from solution, just as is the case with mercuric chloride $(\$ 183)$. Cells were therefore set up containing mercury in contact with a magma of mercurous bromide (freshly precipitated and well washed), suspended in zincbromide solution, and opposed, firstly, to amalgamated zinc immersed in zinc-bromide solution, and, secondly, to electro-

* Zine-cadmium assumed to give the same value for this solutionstrength as that found above for the somewhat stronger solution $25 \mathrm{CaBr}_{2} 100 \mathrm{H}_{2} \mathrm{O}$.

Phil. Mag. S. 5. Vol. 19. No. 118. March 1884. P 
202 Messrs. Wright and Thompson on the Determination of

silver in contact with a magma of silver bromide suspended in zinc-bromide solution, the solution-strength being $\cdot 25 \mathrm{ZnBr}_{2}$ $100 \mathrm{H}_{2} \mathrm{O}$ throughout. The following values were obtained, the current passing, in the latter case, in the direction opposite to that predicable from the relative heats of formation of mercurous and silver bromides :-

\begin{tabular}{|c|c|c|}
\hline & Zinc-Mercury. & Mercury-Silver. \\
\hline 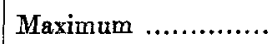 & .974 & -.062 \\
\hline Minimum ….............. & .969 & -.073 \\
\hline Average …….................. & .972 & -066 \\
\hline Probable error .......... & \pm .0006 & $\pm \cdot 0019$ \\
\hline
\end{tabular}

These figures lead to the following valuations for the voltaic constant of mercury in contact with mercurous bromide suspended in $\cdot 25 \mathrm{ZnBr}_{2} 100 \mathrm{H}_{2} \mathrm{O}:-$

$$
\begin{aligned}
& \text { Zinc-mercury . . . . . . . . . . } 972 \\
& \text { Zinc-silver-Mercury-silver } \cdot \cdot\left\{\begin{array}{r}
.906 \\
+\cdot 066
\end{array}\right\}=.972 \\
& \text { Mean . . . } .972
\end{aligned}
$$

Julius Thomsen finds $\mathrm{Hg}_{2}, \mathrm{Br}_{2}=68290$; whence $\mathrm{E}_{\mathrm{H}}=\cdot 500$ volt, corresponding with 22670 gramme-degrees. Hence

$$
\mathrm{E}-\mathrm{E}_{\mathrm{H}}=+\cdot 472 \text {; }
$$

that is, the thermovoltaic constant for mercury in contact with this bromide magma is a large positive quantity, somewhat greater than that observed with the corresponding chloride magma, viz. $+\cdot 458$.

It is noticeable that the heat of formation of mercurous bromide exceeds that of lead-bromide solution $\left(\mathrm{Hg}_{2}, \mathrm{Br}_{2}\right.$ $=68290, \mathrm{~Pb}_{\mathrm{B}} \mathrm{Br}_{2}$ aq. $=54410$, difference 13880 , corresponding with $\cdot 306$ volt); whilst the value of $k_{1}-k_{2}$ for lead-mercurybromide cells is

$$
-\cdot 235-(+\cdot 472)=-\cdot 707 \text {; }
$$

so that $\mathrm{E}_{\mathrm{H}}+k_{1}-k_{2}$ is negative relatively to $\mathrm{E}_{\mathrm{H}}$, being $=-.401$. On examining various such cells (solution-strength $=\cdot 037 \mathrm{MBr}_{2} 100 \mathrm{H}_{2} \mathrm{O}$ ), the E.M.F. was found to be actually of negative sign, the average observed value being $-\cdot 402$.

$$
\text { V. Iron. }
$$

201. A series of cells was examined containing plates of nearly pure sheet iron (bright) opposed to amalgamated zinc 
and electro-cadmium with bromide solutions of the respective metals of strength $\cdot 25 \mathrm{MBr}_{2} 100 \mathrm{H}_{2} \mathrm{O}$ (the ferrous-bromide solutions being prepared by agitating together pure spongy iron in excess and weighed quantities of bromine and water in a stoppered bottle, filtering and using immediately). The following numbers were obtained :-

\begin{tabular}{|c|c|c|}
\hline & Zinc-Iron. & Iron-Cadmium. \\
\hline Maximum ............... & $\cdot 441$ & -.086 \\
\hline Minimum $\ldots . .$. & -401 & $-\cdot 126$ \\
\hline A verage ................... & $\cdot 417$ & $-\cdot 103$ \\
\hline Probable error ......... & $\pm \cdot 005$ & \pm 005 \\
\hline
\end{tabular}

As with the cadmium-iron sulphate and chloride cells, the current passed in the second case in the direction opposite to that predicable from the relative heats of formations of ironand cadmium-bromide solutions; while the E.M.F. actually set up in the first case notably exceeded that similarly calculable from the heats of formation of zinc- and iron-bromide solutions.

These numbers lead to the following valuations for the voltaic constant for bright iron in solution of strength $25 \mathrm{FeBr}_{2}$ $100 \mathrm{H}_{2} \mathrm{O}$ :-

$$
\begin{array}{r}
\text { Zinc-iron . . . . . . } \\
\text { Zinc-cadmium-Cadmium-iron }\left\{\begin{array}{r}
\cdot 315 \\
+\cdot 103
\end{array}\right\}=\frac{\cdot 418}{\cdot 418} \\
\text { Mean . . . }
\end{array}
$$

Julius Thomsen finds $\mathrm{Fe}, \mathrm{Br}_{2}$ aq. $=78070$; whence $\mathrm{E}_{\mathrm{H}}=$ -284 volt, corresponding with 12890 gramme-degrees. Hence

$$
\mathrm{E}-\mathrm{E}_{\mathrm{H}}=+\cdot 134 \text {; }
$$

i. e. the thermovoltaic constant is a notable positive quantity, less, however, in magnitude than the corresponding value for ferrous-chloride solution of the same strength, viz. +204 .

\section{Aluminium.}

202. A number of cells were set up with bright aluminium plates opposed to amalgamated zinc and electro-cadmium, immersed in their respective bromide solutions of strength $-25 \mathrm{MBr}_{2} 100 \mathrm{H}_{2} \mathrm{O}$. The readings exhibited the same fluctuations as were observed with the sulphate and chloride cells previonsly examined $(\$ 178$ and $\$ 186)$. The following readings were obtained, the current passing in the opposite direction to that calculable from the relative heats of forman 
204 Messrs. Wright and Thompson on the Determination of tion of zinc- and aluminium-bromide solutions in the first case, but in the normal direction in the second case :-

\begin{tabular}{|c|c|c|}
\hline & Zinc-Aluminium. & Cadmium-Aluminium. \\
\hline Maximum ............... & -323 & +037 \\
\hline Minimum............ & $-\cdot 278$ & $+\cdot 013$ \\
\hline A verage ................... & $-\cdot 296$ & $+\cdot 022$ \\
\hline Probable error .......... & $\pm \cdot 007$ & $\pm \cdot 005$ \\
\hline
\end{tabular}

These numbers lead to the following valuations for the voltaic constant for bright aluminium in bromide solution $.25 \mathrm{Al}_{\frac{2}{3}} \mathrm{Br}_{2} 100 \mathrm{H}_{2} \mathrm{O}:-$

$$
\begin{aligned}
& \text { Zinc-aluminium . . . . . . . . • . • }+296 \\
& \text { Zinc-cadmium -Aluminium-cadmium }\left\{\begin{array}{r}
\cdot 315 \\
-.022
\end{array}\right\}=+\cdot 293 \\
& \text { Mean . . . } \overline{+\cdot 295}
\end{aligned}
$$

the constant being of + sign, since aluminium actually acquires the higher potential, although it might à priori be expected to acquire the lower potential.

Julius Thomsen's thermochemical data lead to the value $\mathrm{Al}_{\frac{2}{3}}, \mathrm{Br}_{2}$ aq. $=136680$; whence $\mathrm{E}_{\mathrm{H}}=-1.008$ volt, corresponding with 45720 gramme-degrees. Consequently

$$
\mathrm{E}-\mathrm{E}_{\mathrm{H}}=+\cdot 295-(-1 \cdot 008)=+1 \cdot 303 \text {; }
$$

i. e. the thermovoltaic constant for bright aluminium in bromide solution $25 \mathrm{Al}_{\frac{2}{3}} \mathrm{Br}_{2} 100 \mathrm{H}_{2} \mathrm{O}$ is a large positive quantity, slightly greater than that found with the corresponding chloride solution, viz. $+1 \cdot 288$.

F. Voltaic and Thermovoltaic Constants of Metals immersed in Solutions of their Iodides.

\section{Cadmium.}

203. The following values were obtained with a number of cells set up with amalgamated zinc and electro-cadmium immersed in solutions of their iodides of strength $\cdot 25 \mathrm{MI}_{2}$ $100 \mathrm{H}_{2} \mathrm{O}:-$

$$
\begin{aligned}
& \text { Maximum . . . . } \cdot 326 \\
& \text { Minimum . . . . . } \cdot 320 \\
& \text { Average . . . . . } 322 \\
& \text { Probable error . . . } \pm \pm^{\circ} 0008
\end{aligned}
$$


Julius Thomsen finds the heat-values for this strength of solution are $\mathrm{Zn}, \mathrm{I}_{2}, \mathrm{aq} .=60540$, and $\mathrm{Cd}, \mathrm{I}_{2}, \mathrm{aq} .=47870$; whence $\mathrm{E}_{\mathrm{H}}=\cdot 279$ volt, corresponding with 12670 gramme-degrees. Hence $\mathrm{E}-\mathrm{E}_{\mathrm{H}}=+\cdot 043$; i. e. the thermovoltaic constant for cadmium in iodide solution of strength $\cdot 25 \mathrm{CdI}_{2} 100 \mathrm{H}_{2} \mathrm{O}$ is positive in sign but not large numerically. It is noteworthy that, with the corresponding bromide and chloride solutions, the values were negative, viz. -.023 and -.036 respectively; the bromide value being thus intermediate between the chloride and iodide values.

\section{Silver.}

204. The following numbers were obtained with cells set up with electro-silver immersed in a magma of freshly precipitated well-washed silver iodide suspended in zinc iodide solution, and opposed to amalgamated zinc or electro-cadmium in their respective iodide solutions, the solution-strength being uniformly $\cdot 25 \mathrm{MI}_{2} 100 \mathrm{H}_{2} \mathrm{O}$.

\begin{tabular}{|c|c|c|}
\hline & Zinc-Silver. & Cadmium-Silver. \\
\hline Maximum ................ & 713 & 393 \\
\hline Minimum ................ & $\cdot 696$ & $\cdot 374$ \\
\hline Average $. . . . . . . . \ldots \ldots . .$. & $\cdot 7055$ & $\cdot 384$ \\
\hline Probable error ......... & $\pm \cdot 0028$ & \pm 0030 \\
\hline
\end{tabular}

These values lead to the following valuations of the voltaic constant for electro-silver in contact with this magma :-

$$
\begin{aligned}
& \text { Zinc-silver . . . . . . . . . . . } 7055 \\
& \text { Zinc-cadmium + Cadmium-silver }\left\{\begin{array}{r}
\cdot 322 \\
+\cdot 384
\end{array}\right\}==706 \\
& \text { Mean . . . } \overline{\cdot 706}
\end{aligned}
$$

Since Thomsen finds $\mathrm{Ag}_{2}, \mathrm{I}_{2}=27600$, the value of $\mathrm{E}_{\mathrm{H}}$ is $726^{2}$ volt, corresponding with 32940 gramme-degrees : hence $\mathrm{E}-\mathrm{E}_{\mathrm{H}}=-.020$.

On comparing this value with those found for silver bromide suspended in zinc-bromide solution and for silver chloride suspended in zinc-chloride solution, all of the same strength $.25 \mathrm{ZnX}_{2} 100 \mathrm{H}_{2} \mathrm{O}$, viz. - .099 and -.112 volt respectively, it is noticeable that the direction of variation is the same as that observed in the analogous cases for cadmium, the bromide value being intermediate between the chloride and iodide values, the last being algebraically the greatest. 


\section{Mercury.}

205. Cells were set up with mercury in contact with freshly precipitated mercurous iodide suspended in zinc-iodide solution, and opposed, firstly, to amalgamated zine in zinc-iodide solution, and, secondly, to electro-silver immersed in a magma of freshly precipitated silver-iodide and zinc-iodide solution, the solution-strength being uniformly $25 \mathrm{ZnI}_{2} \quad 100 \mathrm{H}_{2} \mathrm{O}$. The following values were obtained :-

\begin{tabular}{|c|c|c|}
\hline & Zinc-Mercury. & Mercury-Silver. \\
\hline Marimum ............ & $\cdot 806$ & -.092 \\
\hline Minimum .............. & $\cdot 797$ & $-\cdot 101$ \\
\hline Average ..................... & $\cdot 800$ & -.096 \\
\hline Probable error .......... & \pm 0013 & $\pm \cdot 0014$ \\
\hline
\end{tabular}

the current passing in the latter case in the direction opposite to that predicable from the relative heats of formation of silver and mercurous iodides. From these values the following valuations result for the voltaic constant of mercury in contact with mercurous iodide suspended in $\cdot 25 \mathrm{ZnI}_{2} 100 \mathrm{H}_{2} \mathrm{O}$ :-

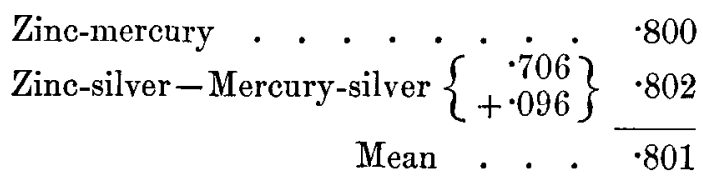

Julius Thomsen finds that $\mathrm{Hg}_{2}, \mathrm{I}_{2}=48440$; whence $\mathrm{E}_{\mathrm{H}}=$ $\cdot 267$ volt, corresponding with 12100 gramme-degrees. Hence $\mathrm{E}-\mathrm{E}_{\mathrm{H}}=+.534 ;$ i. e. the thermovoltaic constant for mercury in contact with a magma of mercurous iodide suspended in $.25 \mathrm{ZnI}_{2} 100 \mathrm{H}_{2} \mathrm{O}$ is a large positive quantity, as similarly found for mercury in contact with mercurous-bromide and zinc-bromide solution and with mercurous-chloride and zincchloride solution of the same solution-strength, these latter two values being respectively $+\cdot 472$ and $+\cdot 458$. So that the bromide value is intermediate between the values for chloride and iodide; whilst the direction of variation with the three halogens is the same as that observed both with cadmium and with silver, viz. that the iodide value is algebraically the greatest.

$$
\text { IV. Lead. }
$$

206. The very sparing solubility of lead iodide rendered it impracticable to obtain good readings with cells set up with 
aqueous solutions of that salt. Accordingly a magma of leadjodide and zinc-iodide solution of strength $\cdot 25 \mathrm{ZnI}_{2} 100 \mathrm{H}_{2} \mathrm{O}$ was employed to surround the electro-lead plates used, opposed in one set of experiments to amalgamated zinc in the same zinc-iodide solution, and in another set to mercury immersed in a magma of mercurous iodide suspended in the same zinciodide solution. The following values were obtained, the degree of concordance being distinctly less than with most of the other combinations examined :-

\begin{tabular}{|c|c|c|}
\hline & Zinc-Lead. & Lead-Mercury. \\
\hline Maximum .............. & $\cdot 489$ & -317 \\
\hline Minimum ............... & $\cdot 418$ & -379 \\
\hline Average .................. & $\cdot 455$ & -347 \\
\hline Probable error ......... & \pm 009 & $\pm \cdot 008$ \\
\hline
\end{tabular}

The lead-mercury cells gave a current in the direction opposite to that deducible from the relative heats of formation of zinc and mercurous iodides.

From these numbers the following valuations of the voltaic constant result :-

$$
\begin{array}{r}
\text { Zinc-lead . . . . . . } \\
\text { Zinc-mercury + Mercury-lead }\left\{\begin{array}{r}
\cdot 801 \\
-347
\end{array}\right\}=\frac{}{\cdot 455} \\
\text { Mean . . . . } \frac{\cdot 455}{455}
\end{array}
$$

Julius Thomsen finds $\mathrm{Pb}, \mathrm{I}_{2}=39800$; whence $\mathrm{E}_{\mathrm{H}}=\cdot 457$. Hence the thermovoltaic constant for electro-lead immersed in a magma of lead iodide suspended in $\cdot 25 \mathrm{ZnI}_{2} 100 \mathrm{H}_{2} \mathrm{O}$ is a minute negative quantity, viz. $-\cdot 002$.

This value and those above found for electro-lead in contact with saturated-chloride and bromide-of-lead solutions respectively, viz. $-\cdot 222$ and $-\cdot 235$, are not strictly comparable, since the solution-strength was not the same throughout; whilst a magma containing zinc-iodidrs solntion was used for the iodide cells and pure lead-salts for the others, which, moreover, had respectively the strengths $0 \mathrm{E}_{1} \mathrm{PbCl}_{2} 100 \mathrm{H}_{2} \mathrm{O}$, and $037 \mathrm{PbBr}_{2} 100 \mathrm{H}_{2} \mathrm{O}$. Probably from these causes the bromide value is not intermediate between the chloride and iodide values, as might have been anticipated; but the last 


\section{Messrs. Wright and Thompson on the Determination of}

value is algebraically the greatest, as was found with cadmiumsilver and mercury.

It is hence evident that whilst the thermovoltaic constants of metals in contact with their oxy salts (sulphates, nitrates, and acetates) do not vary widely, the same remark is not true for their halogen salts (chlorides, bromides, iodides). In general the thermovoltaic constant is decreased (algebraically) by substitution of bromide for iodide or of chloride for bromide; although this rule is not without exception, e.g. in the case of iron, where the values for $25 \mathrm{FeX}_{2} 100 \mathrm{H}_{2} \mathrm{O}$ are $+\cdot 204$ and $+\cdot 134$, where $\mathrm{X}$ represents chlorine and bromine respectively, the substitution of chlorine for bromine thus causing a notable increase.

\section{Summary of Results.}

207. The experiments above described lead to the general conclusion that electromotors, consisting of voltaic cells in which two different metals are surrounded by solutions of corresponding salts respectively, are capable of generating electromotive forces which (when not depreciated sensibly below their maximum value by giving rise to currents of densities greater than certain small limiting values) usually stand in no simple relationship to the chemical action taking place in the cell during the passage of the currrent, or to the heat-evolution taking place during that passage, or to the heats of formation of the two solutions electrolyzed. The values of the maximum E.M.F.'s thus generated may, however, be deduced within very close limits of accuracy by taking the algebraic difference between certain numerical values or voltaic constants assigned to each metal in contact with each given solution, these values varying slightly according to the surface-nature of the immersed metal, and being also dependent on the nature and strength of the solution of metallic salt in contact with the metal, and probably also varying with the temperature, but being otherwise actually constant.

Further, these maximum E.M.F. values may be connected with the difference in heat of formation between the two solutions electrolyzed by supposing that the total difference of potential set up is due to two superposed causes:-one, the heatevolution due to the difference in heat of formation of the two solutions, which tends to make the metal immersed in the electrolyte of lesser formation-heat acquire the higher potential (like the copper plate of a Daniell cell); the other, a thermovoltaic action akin to the modus operandi of an ordinary 
thermovoltaic couple, in virtue of which a difference of potential is set up expressible by the algebraic difference between two numerical values, or thermovoltaic constants, assignable to each metal respectively, the which values vary pari passu with the variations in the corresponding voltaic constants. This thermovoltaic action being expressible by $k_{1}-k_{2}$, and the first source of potential-difference being indicated by $\mathrm{E}_{\mathrm{H}}$, the total difierence of potential set up is

$$
\mathrm{E}=\mathrm{E}_{\mathrm{H}}+k_{1}-k_{2} \text {, }
$$

where, if $k_{1}-k_{2}$ be materially different from zero (which is most frequently the case), the value of $\mathrm{E}$ will differ materially from that of $\mathrm{E}_{\mathrm{H}}$, exceeding or falling short of it according as $k_{1}-k_{2}$ is positive or negative in sign with respect to $\mathrm{E}_{\mathrm{H}}$. In the latter case, if $k_{1}-k_{2}$ be numerically greater than $E_{H}$, the direction of the current actually generated is the reverse of that predicable from the relative heats of formation of the electrolytes.

208. The following Table furmishes a brief epitome of the mean values of the voltaic and thermovoltaic constants deduced above for various metals and fluids at a temporature within a very few degrees above or below $18^{\circ} \mathrm{C}$.; the solutions surrounding both plates being of equal strength ( $m$ zinc-salt molecules per 100 water molecules), the plate-surfaces being freshly amalgamated ones for zinc (standard), bright fused metal for iron, magnesium, and aluminium, and freshly electro-coated plates in all other cases.

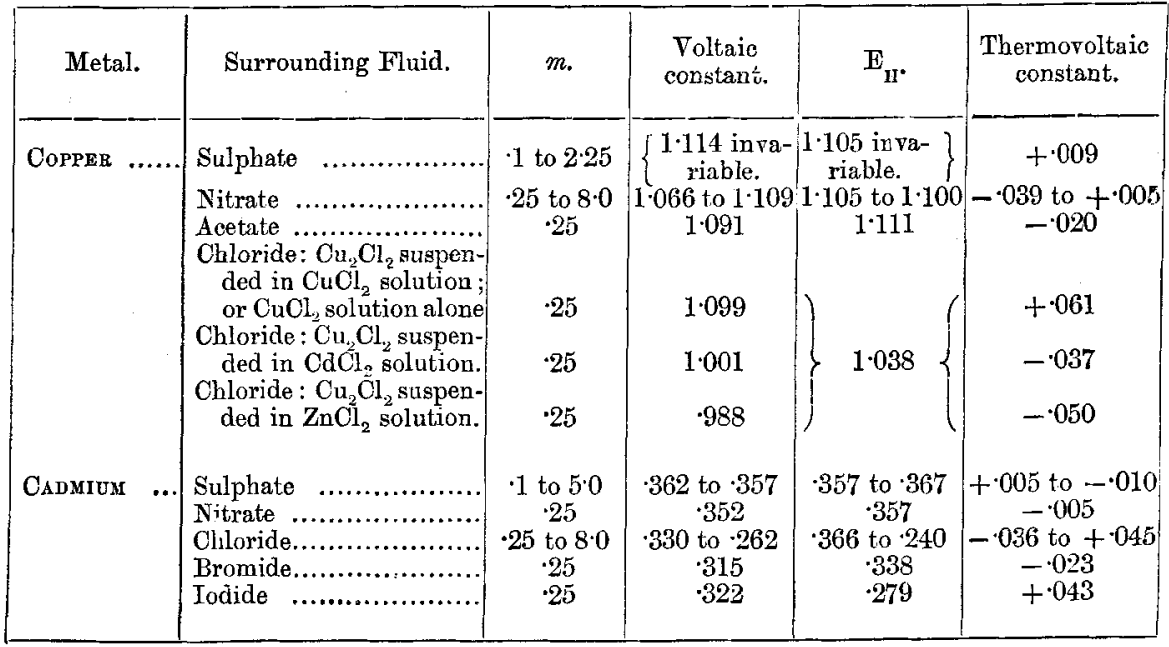


210 Messrs. Wright and Thompson on the Determination of

Table (continued).

\begin{tabular}{|c|c|c|c|c|c|}
\hline Metal. & Surrounding Fluid. & $m$ & $\begin{array}{l}\text { Voltaic } \\
\text { constant. }\end{array}$ & $\mathbf{E}_{\mathrm{H}}^{*}$ & $\begin{array}{l}\text { Thermovoltaic } \\
\text { constant. }\end{array}$ \\
\hline \multirow[t]{7}{*}{ SHLYER } & $\begin{array}{l}\text { Sulphate } \ldots \ldots \ldots \ldots \ldots \ldots \\
\text { Nitrate } \ldots \ldots \ldots \ldots \ldots \ldots \ldots\end{array}$ & $\begin{array}{c}042 \\
25 \text { to } 20\end{array}$ & $\mid \begin{array}{c}1.539 \\
1 \cdot 495 \text { to } 1.556\end{array}$ & $\begin{array}{l}1.890 \\
1 \cdot 890\end{array}$ & -395 to -351 \\
\hline & 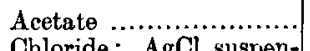 & $\cdot 057$ & 1.489 & $?$ & $\begin{array}{c}\text { Probably near } \\
\text { to }-40\end{array}$ \\
\hline & ded in $\mathrm{ZnCl}_{2}$ solution. & .25 to 6.0 & 1.080 to $1.014 \mid$ & $1 \cdot 192$ to 1.076 & -112 to -.062 \\
\hline & $\begin{array}{l}\text { ded in } \mathrm{CdCl}_{2} \text { solution. } \\
\text { Chloride: } \mathrm{AgCl} \text { suspen- }\end{array}$ & .25 & 1.089 & $1 \cdot 192$ & $-\cdot 103$ \\
\hline & $\begin{array}{l}\text { ded in } \mathrm{CuCl}_{2} \text { solution. } \\
\text { Bromide: } \mathrm{AgBr} \text { suspen. }\end{array}$ & $\cdot 25$ & $1 \cdot 137$ & & $-\cdot 055$ \\
\hline & $\begin{array}{r}\text { ded in } \mathrm{ZnBr}_{2} \text { solution. } \\
\text { Iodide: } \mathrm{AgI} \text { suspended }\end{array}$ & $\cdot 25$ & $\cdot 906$ & $1 \cdot 005$ & $-\cdot 099$ \\
\hline & in $\mathrm{ZnI}_{2}$ solution........... & $\cdot 25$ & 706 & 726 & -.020 \\
\hline \multirow[t]{5}{*}{ LEAD .......... } & $\begin{array}{r}\text { Sulphate: } \mathrm{PbSO}_{4} \text { suspen- } \\
\text { ded in } \mathrm{ZnSO}_{1} \text { solution. } \\
\text { Sulphate: } \mathrm{PbSO}_{4} \text { suspen- }\end{array}$ & $\cdot 1$ to 50 & 536 to 487 & $\begin{array}{c}712 \text { to } \\
704\end{array}$ & $-\cdot 176$ to $-\cdot 217$ \\
\hline & $\begin{array}{l}\text { ded in } \mathrm{CdSO}_{4} \text { solution. } \\
\text { Nitrate }\end{array}$ & $\begin{array}{l}\cdot 1 \text { to } 5 \cdot 0 \\
.25 \text { to } 2 \cdot 0\end{array}$ & $\begin{array}{l}\cdot 550 \text { to } \cdot 505 \\
\cdot 580 \text { to } \cdot 591\end{array}$ & 759 to 716 & $\left|\begin{array}{l}-\cdot 162 \text { to }-\cdot 199 \\
-\cdot 179 \text { to }-\cdot 125\end{array}\right|$ \\
\hline & Acetate ......................... & .25 & $\begin{array}{l}.607 \\
.591\end{array}$ & $\begin{array}{l}.770 \\
.813\end{array}$ & -163 \\
\hline & 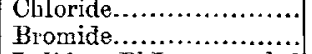 & $\begin{array}{l}.05 \\
.037\end{array}$ & $\begin{array}{l}591 \\
571\end{array}$ & 806 & -235 \\
\hline & $\begin{array}{l}\text { Todide: } \mathrm{PbI}_{2} \text { suspended } \\
\quad \text { in } \mathrm{ZnI} \mathrm{I}_{2} \text { solution......... }\end{array}$ & .25 & $\cdot 455$ & 457 & -.002 \\
\hline \multirow[t]{2}{*}{ Tron } & Sulphate....................... & $0 \cdot 1$ to $1 \cdot 0$ & $\cdot 432$ to 398 & 284 & $+\cdot 148$ to $+\cdot 114$ \\
\hline & 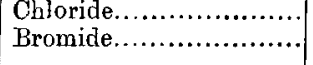 & $\begin{array}{l}\cdot 25 \\
-25\end{array}$ & $\begin{array}{l}\cdot 488 \\
\cdot 418\end{array}$ & $\begin{array}{l}.284 \\
.284\end{array}$ & $\begin{array}{l}+.204 \\
+.134\end{array}$ \\
\hline \multirow[t]{7}{*}{ MERCuRY } & $\begin{array}{r}\text { Sulphate: } \mathrm{Hg}_{2} \mathrm{SO}_{4} \text { suspen- } \\
\text { ded in } \mathrm{ZnSO}_{4} \text { solution. }\end{array}$ & $\cdot 1$ to $5 \cdot 75$ & 1.457 to $1.514 \mid$ & $?$ & $\begin{array}{l}\text { Probably near } \\
+\cdot 25 \text { to }+\cdot 00\end{array}$ \\
\hline & $\begin{array}{l}\text { Nitrate (mercurous) ...... } \\
\text { Chloride : } \mathrm{Hg}_{\mathrm{Cl}} \text { suspen- }\end{array}$ & $\cdot 25$ & 1.499 & $1 \cdot 202$ & +297 \\
\hline & $\begin{array}{l}\text { ded in } \mathrm{HgCl}_{2} \text { solution. } \\
\text { Chloride: } \mathrm{Hg}_{0} \mathrm{Cl}_{2} \text { suspen- }\end{array}$ & $\cdot 25$ & $1 \cdot 257$ & $\cdot 668$ & +589 \\
\hline & $\begin{array}{l}\text { ded in } \mathrm{CdCl}{ }_{2} \text { solution. } \\
\text { Chloride: } \mathrm{Hg}_{2} \mathrm{Cl}_{2} \text { suspen- }\end{array}$ & .25 & $1 \cdot 141$ & & +-473 \\
\hline & ded in $\mathrm{ZnCl}_{2}$ solution. & $\cdot 25$ to $9-5$ & 1.123 to 988 & 668 to 536 & +455 to +481 \\
\hline & ded in $\mathrm{ZnBr}_{2}$ solution & $\cdot 25$ & .972 & $\cdot 500$ & $+\cdot 472$ \\
\hline & $\begin{array}{l}\text { odide : } \mathrm{Hg}_{2} \mathrm{I}_{2} \text { suspended } \\
\text { in } \mathrm{ZnI} \mathrm{I}_{2} \text { solution.......... }\end{array}$ & $\cdot 25$ & .801 & -267 & $+\cdot 534$ \\
\hline \multirow[t]{2}{*}{ Magnesiun. } & Sulphate.................... & $1 \cdot 0$ & -.725 & $-1 \cdot 634$ & +909 \\
\hline & 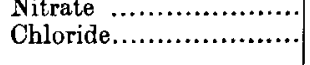 & $\begin{array}{l}\cdot 25 \\
\cdot 25\end{array}$ & $\begin{array}{l}-.630 \\
-.701\end{array}$ & $\begin{array}{l}-1 \cdot 631 \\
-1 \cdot 634\end{array}$ & $\begin{array}{l}+1.101 \\
+\quad 933\end{array}$ \\
\hline \multirow[t]{2}{*}{ AluMiniUM... } & Sulphate... & 5 & $+\cdot 537$ & -.982 & +1.519 \\
\hline & 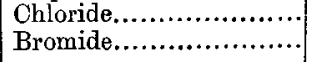 & $\begin{array}{l}.25 \\
.25\end{array}$ & $\begin{array}{l}+\cdot 280 \\
+\cdot 295\end{array}$ & $\begin{array}{l}-1 \cdot 008 \\
-1 \cdot 008\end{array}$ & $\begin{array}{l}+1.288 \\
+1.303\end{array}$ \\
\hline & & & & & \\
\hline
\end{tabular}


209. The following is a list of the cells examined, in which the value of $k_{1}-k_{2}$ is opposite in sign to, and numerically greater than, $E_{H}$; so that the current actually generated Hows in the direction opposite to that predicable from the relative heats of formation of the electrolytes:-

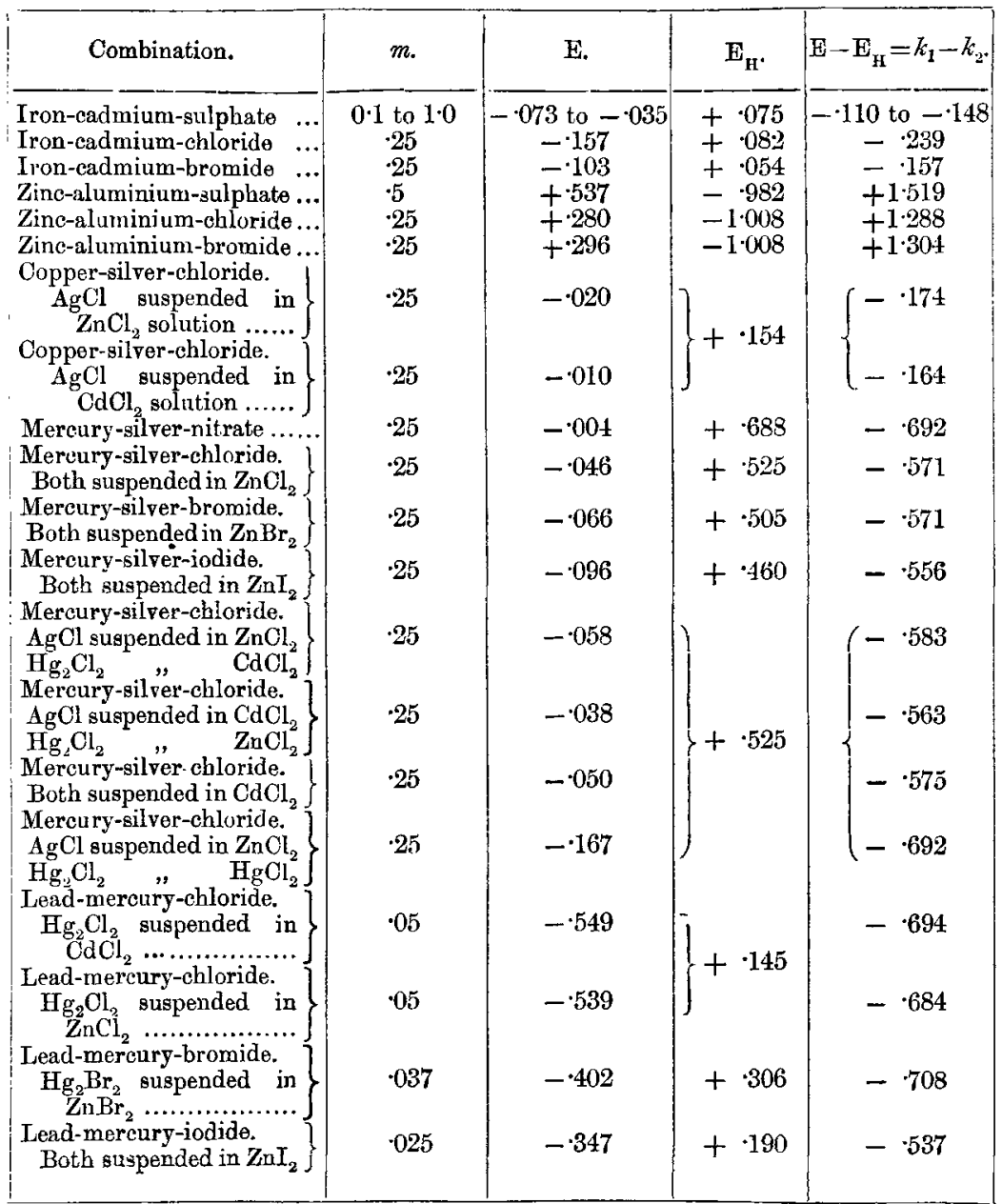

210. The following is a list of the cells examined in which the value of $k_{1}-k_{2}$ is of the same sign as $\mathrm{E}_{\mathrm{H}}$; so that the E.M.F. actually set up exceeds in numerical value that predicable from the relative heats of formation of the electrolytes ; only those cells are named where the excess is somewhat considerable, i. e. $0 \cdot 1$ volt or upwards. 
212 Messrs. Wright and Thompson on the Determination of

\begin{tabular}{|c|c|c|c|c|}
\hline Combination. & $m$. & E. & $\mathbf{E}_{\mathbf{H}}$ & Excess. \\
\hline $\begin{array}{l}\text { Lead-copper-sulphate. } \\
\mathrm{PbSO} \text { suspended in } \mathrm{ZnSO}\end{array}$ & 0.1 to $2 \cdot 0$ & ) 577 to $\cdot 611$ & & {$[+\cdot \cdot 184$ to $+\cdot 217$} \\
\hline $\begin{array}{r}\text { solution ........................ } \\
\text { Lead-copper-sulphate. }\end{array}$ & $\mid \begin{array}{lll}0 & 1 & 0\end{array}$ & (3) & -393 to 394 & $1+10420+211$ \\
\hline $\left.\begin{array}{ccc}\mathrm{PbSO}_{4} & \text { suspended } \\
\mathrm{CdSO}_{4} \text { solution..................... }\end{array}\right\}$ & $\mid 0 \cdot 1$ to $2 \cdot 0 \mid$ & 564 to .596 & & $l+\cdot 171$ to $+\cdot 202$ \\
\hline 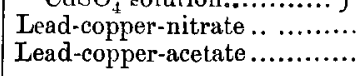 & $\left|\begin{array}{c}25 \text { to } 2 \cdot 0 \\
.25\end{array}\right|$ & $\begin{array}{c}486 \text { to } \cdot 519 \\
\cdot 485\end{array}$ & $\begin{array}{l}345 \text { to } \cdot 388 \\
\quad 341\end{array}$ & $\begin{array}{c}+\cdot 141 \text { to }+\cdot 128 \\
+\cdot 144\end{array}$ \\
\hline Lead-copper-chloride ......... & .05 & $\left\{\begin{array}{l}\text { Irregular, } \\
\text { about } \cdot 475\end{array}\right.$ & $\cdot 225$ & About $+\cdot 25$ \\
\hline $\begin{array}{ll}\text { Zinc-iron-sulphate } & \ldots \ldots \ldots \ldots \ldots \\
\text { Zinc-iron chloride } & \ldots \ldots \ldots \ldots \\
\text { Zinc-iron-bromide } & \ldots \ldots \ldots \ldots\end{array}$ & $\left|\begin{array}{c}0 \cdot 1 \text { to } 1 \cdot 0 \\
25 \\
25\end{array}\right|$ & $\begin{array}{c}445 \text { to } \cdot 399 \\
\cdot 490 \\
\cdot 417\end{array}$ & $\begin{array}{l}\cdot 284 \\
.284 \\
\cdot 284\end{array}$ & $\begin{array}{c}+\cdot 161 \text { to }+\cdot 115 \\
+\cdot 206 \\
+\cdot 133\end{array}$ \\
\hline Zinc-mercury-sulpbate......... & .1 to 575 & 1.514 to 1.457 & $?$ & $\left\{\begin{array}{c}\text { Probably about } \\
+\cdot 3\end{array}\right.$ \\
\hline $\begin{array}{l}\text { Zinc-mercury-nitrate } \\
\text { Zinc-mercury-chloride. }\end{array}$ & $\cdot 25$ & $1 \cdot 500$ & $1 \cdot 202$ & +298 \\
\hline $\left.\begin{array}{c}\mathrm{Hg}_{2} \mathrm{Cl}_{2} \text { suspended in } \\
\mathrm{HgCl}_{2} \text { solution ................ }\end{array}\right\}$ & .25 & $1 \cdot 256$ & & $+\cdot 588$ \\
\hline 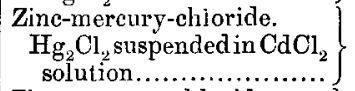 & $\cdot 25$ & $1 \cdot 140$ & 668 & +572 \\
\hline 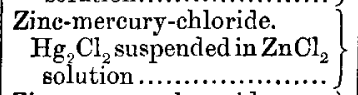 & $\because 5$ to $9 \cdot 5$ & $1 \cdot 123$ to $\cdot 988$ & $\cdot 668$ to $\cdot 536$ & $+\cdot 452$ to $+\cdot 481$ \\
\hline $\left.\begin{array}{cc}\text { Zinc-mercury-bromide. } \\
\mathrm{Hg}_{2} \mathrm{Br}_{2} & \text { suspended } \\
\mathrm{ZnBr}_{2} & \text { solution } \ldots . . . \ldots \ldots . . . .\end{array}\right\}$ & .25 & $\cdot 972$ & .500 & $+\cdot 472$ \\
\hline 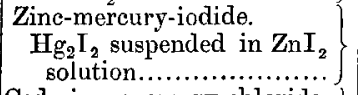 & $\cdot 25$ & .800 & $\cdot 267$ & $+\cdot 533$ \\
\hline $\begin{array}{r}\text { Cadmium-mercury chloride. } \\
\mathrm{Hg}_{2} \mathrm{Cl}_{2} \text { suspended in } \\
\mathrm{HgCl}_{2} \text { solution ............. } \\
\text { Cadmium-mercury-chloride. }\end{array}$ & $\cdot 25$ & $\cdot 929$ & ) & +627 \\
\hline $\begin{array}{r}\mathrm{Hg}_{2} \mathrm{Cl}_{2} \text { suspended in } \\
\mathrm{CdCl}{ }_{2} \text { solution ................... } \\
\text { Cadmium-mercury-chloride. }\end{array}$ & $\cdot 25$ & $\cdot 812$ & $\cdot 302$ & +-510 \\
\hline $\left.\begin{array}{r}\mathrm{Hg}_{2} \mathrm{Cl}_{2} \text { suspended in } \\
\mathrm{ZnCl}_{2} \text { solution } \ldots \ldots \ldots \ldots \ldots . . . . .\end{array}\right\}$ & .25 & 799 & & $+\cdot 497$ \\
\hline $\begin{array}{l}\text { Copper-mercury-nitrate } . . . . . \\
\text { Lead-mercury-nitrate } . . . . \ldots \ldots\end{array}$ & $\begin{array}{l}\cdot 25 \\
.25\end{array}$ & $\begin{array}{l}.433 \\
.917\end{array}$ & $\begin{array}{l}\cdot 097 \\
\cdot 443\end{array}$ & $\begin{array}{l}+336 \\
+\cdot 474\end{array}$ \\
\hline $\begin{array}{l}\text { Lead-mercury-nitrate } \\
\text { Lead-silver-chloride. }\end{array}$ & & -917 & $\cdot 443$ & \\
\hline $\begin{array}{c}\mathrm{AgCl} \text { suspended in } \mathrm{ZnCl} \\
\text { solution } \ldots \ldots \ldots \ldots \ldots \ldots \ldots\end{array}$ & .05 & $\cdot 489$ & & $+\cdot 110$ \\
\hline $\begin{array}{l}\text { Lead-silver-chloride. } \\
\text { AgCl suspended in } \mathrm{PbCl}_{2} \\
\text { solution.................... }\end{array}$ & $\cdot 05$ & $\cdot 480$ & 379 & $+\cdot 101$ \\
\hline
\end{tabular}

211. The following is a list of the cells examined in which the value of $k_{1}-k_{2}$ is of the opposite sign to, but not greater in magnitude than, $E_{H}$; so that the E.M.F. actually set up is less in numerical value than that predicable from the relative heats of formation of the electrolytes; only those cells are 


\section{Chemical Affinity in terms of Electromotive Force. 213}

named where the deficiency is somewhat considerable, viz. 0.1 volt and upwards.

\begin{tabular}{|c|c|c|c|c|}
\hline Combination. & $m$. & E. & $\mathrm{E}_{\mathrm{H}}$. & Deficiency. \\
\hline Zinc-silver-sulphate ............. & $\cdot 042$ & $1 \cdot 536$ & 1.890 & -354 \\
\hline Zinc-silver-nitrate ............ & 25 to 2.0 & 1.495 to 1.556 & $1 \cdot 890$ & 395 to $36 t$ \\
\hline Zinc-silrer-acetal $\theta \quad \ldots \ldots \ldots \ldots \ldots$ & .057 & 1.490 & $?$ & Probably near 40 \\
\hline $\begin{array}{l}\text { Zinc-silver-chloride. } \\
\mathrm{AgCl} \text { suspended in } \mathrm{ZnCl}_{2}\end{array}$ & .25 to 6.0 & 1.080 to 1.014 & 1.192 to 1.076 & $\cdot 116$ to $\cdot 062$ \\
\hline solution ....................... & & & & 11000004 \\
\hline $\left.\begin{array}{l}\text { Zinc-silver-chloride. } \\
\mathrm{AgCl} \text { suspended in } \mathrm{CdCl}_{2} \\
\text { solution } \ldots \ldots \ldots \ldots \ldots \ldots \ldots\end{array}\right\}$ & $\cdot 25$ & $1 \cdot 088$ & $1 \cdot 192$ & $\cdot 104$ \\
\hline Copper-sil rer-sulphate............ & $\begin{array}{c}042 \\
.05 \text { to } 2 \cdot 0\end{array}$ & $\begin{array}{c}.4235 \\
.429 \text { to } \cdot 446\end{array}$ & $\begin{array}{c}\cdot 785 \\
.785 \text { to } \cdot 786\end{array}$ & $\begin{array}{c}3615 \\
.356 \text { to } 340\end{array}$ \\
\hline Copper-silver-acetate $\ldots . .$. & .057 & 397 & $?\{$ & Probably about \\
\hline Copper-silver-chloride. & & & & \\
\hline 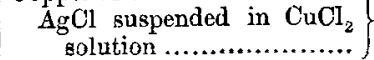 & $\cdot 25$ & $\cdot 035$ & $\cdot 154$ & $\cdot 119$ \\
\hline Gadmium-silvel-sulphate...... & .042 & $1 \cdot 1805$ & 1.533 & 3525 \\
\hline Zinc-lead-sulphate. & & & ) & \\
\hline $\begin{array}{r}\mathrm{PbSO}_{4} \text { suspended in } \mathrm{ZnSO}_{4} \\
\text { solution } \ldots \ldots \ldots \ldots \ldots \ldots \ldots \ldots\end{array}$ & $\cdot 1$ to $5 \cdot 0$ & 537 to $\cdot 487$ & & ' 175 to 217 \\
\hline Zinc-lead-sulphate. & & & 712 to 704 & \\
\hline $\begin{array}{c}\mathrm{PbSO}_{4} \text { suspended in } \mathrm{CdSO}_{4} \\
\text { solution } \ldots \ldots \ldots \ldots \ldots \ldots \ldots \ldots\end{array}$ & 1 to $5 \cdot 0$ & $\cdot 550$ to $\cdot 505$ & & $\cdot 162$ to $\cdot 199$ \\
\hline Zinc-lead-nitrate ................ & 25 to $2 \cdot 0$ & 580 to 591 & 759 to $\cdot 716$ & $\cdot 179$ to $\cdot 125$ \\
\hline Zinc-lead-acetate ............ & .25 & $\cdot 608$ & 770 & $\cdot 162$ \\
\hline Zinc-lead-chloride & .05 & 591 & .813 & 222 \\
\hline Zinı-lead-bromide ,........ & .037 & .571 & 806 & -230 \\
\hline Cadmium-]ead-sulphate ....... & $\cdot 1$ to 30 & 173 to $\cdot 133$ & 355 to $\cdot 345$ & $\cdot 182$ to $\cdot 212$ \\
\hline Cadmium-lead-chloride $\ldots . . . .$. & $\cdot 05$ & $\cdot 260$ & $\cdot 447$ & $\cdot 187$ \\
\hline Cadmium-lead-bromide ... & .037 & .256 & $\cdot 468$ & 212 \\
\hline $\begin{array}{l}\text { Lead-sil ier-sulphate. } \\
\text { PbSO in ZnSO solutio }\end{array}$ & .042 & 1.c03 & $1 \cdot 1775$ & $\cdot 1745$ \\
\hline Lead-silver-nitrate ................ & 25 to $2 \cdot 0$ & ) .914 to 965 & $1 \cdot 131$ to $1 \cdot 174$ & 217 to $\cdot 207$ \\
\hline Lead-silver-acetate $\quad . . . . . . . . .$. & .037 & $\left\{\begin{array}{l}\text { Irregular, } \\
\text { about } 0.8\end{array}\right.$ & ? & Probably about $\cdot 3$ \\
\hline Iron-lead-sulphate. & & & & \\
\hline $\begin{array}{r}\mathrm{PbSO}{ }_{4} \text { suspended in } \mathrm{ZnSO}_{4} \\
\text { solution } \ldots \ldots \ldots \ldots \ldots \ldots \ldots\end{array}$ & 1 to $1 \cdot 0$ & $\cdot 120$ to $\cdot 112$ & $\cdot 428$ & 308 to 316 \\
\hline Ironl-copper-sulphate .......... & 1 to $1 \cdot 0$ & $\cdot 685$ to 715 & 821 & $\cdot 136$ to $\cdot 106$ \\
\hline Iron-silver-sulphate......... & .042 & $1 \cdot 103$ & $1 \cdot 605$ & .502 \\
\hline $\left.\begin{array}{l}\text { Irolt-silver-ehloride. } \\
\mathrm{AgCl} \text { in } \mathrm{ZnCl}_{2} \text { solution....... }\end{array}\right\}$ & $\therefore 25$ & .592 & 908 & $\cdot 316$ \\
\hline Zinc-magnesium-sulphate ....... & $1 \cdot 0$ & 724 & $1 \cdot 634$ & $\cdot 910$ \\
\hline Zine-magnesium-nitrate .. & $\cdot 25$ & .531 & $1 \cdot 631$ & $1 \cdot 100$ \\
\hline Zinc-magnesium-chloride .. & .25 & 702 & $1 \cdot 634$ & .932 \\
\hline Copper-magnesium-sulphate & 1.0 & $1 \cdot 810$ & 2.739 & 899 \\
\hline Copper-magnesium-nitrate ..... & 25 & $159 \overline{5}$ & $2 \cdot 736$ & $1 \cdot 141$ \\
\hline Cadmiuin-magnesium-chloride & .25 & $1 \cdot(130$ & 2000 & .970 \\
\hline Aluminium-copper-sulphate .. & 5 & 578 & 2.087 & 1.509 \\
\hline Aluninium-cadmium-chloride & $\cdot 25$ & .050 & $1 \cdot 374$ & $1 \cdot 324$ \\
\hline Aluminium-cadminm-bromide & .25 & .022 & 1.346 & $1 \cdot 324$ \\
\hline
\end{tabular}


212. The following is a list of the cells examined in which the value of $k_{1}-k_{2}$ is not numerically greater than $\mathrm{E}_{\mathrm{H}}$, and lies within the limits $\pm 0 \cdot 1$ volt. It is evident that the number of cells coming into this category is only a fraction of the total number of combinations examined.

\begin{tabular}{|c|c|c|c|c|}
\hline Combination. & $m$ & $\mathbf{E}$. & $\mathrm{E}_{\mathrm{H}}$ & Differences. \\
\hline Zine-copper-sulphate . & 25 to $2 \cdot 25$ & $\left\{\begin{array}{c}1 \cdot 114 \\
\text { invariable }\end{array}\right.$ & $\begin{array}{c}1 \cdot 105 \\
\text { invariable }\end{array}$ & \}$\quad+.009$ \\
\hline 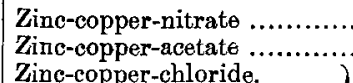 & $\mid \begin{array}{c}25 \text { to } 8 \cdot 0 \\
25\end{array}$ & $\mid \begin{array}{c}1.066 \text { to } 1.091 \\
1.091\end{array}$ & $\left|\begin{array}{c}1 \cdot 105 \text { to } 1 \cdot 100 \\
1 \cdot 111\end{array}\right|$ & $\begin{array}{c}+.005 \text { to }-.039 \\
-020\end{array}$ \\
\hline $\left.\begin{array}{r}\text { Zinc-copper-chloride. } \\
\mathrm{Cu}_{2} \mathrm{Cl}_{2} \text { suspended in } \mathrm{CuCl}_{2} \\
\text { sol,, or } \mathrm{CuCl}, \text { sol. alone... }\end{array}\right\}$ & .25 & 1.0985 & & +.061 \\
\hline $\left.\begin{array}{r}\text { Zinc-copper-chloride. } \\
\mathrm{Cu}_{2} \mathrm{Cl}_{2} \text { suspended in } \mathrm{CdCl}_{2} \\
\text { solution } \ldots \ldots \ldots \ldots \ldots \ldots \ldots \ldots\end{array}\right\}$ & $\cdot 25$ & $1 \cdot 001$ & $1 \cdot 038$ & -.037 \\
\hline 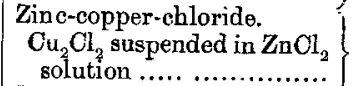 & $\cdot 25$ & 988 & & $-\cdot 050$ \\
\hline $\begin{array}{l}\text { Zinc-cadmium-sulphate } \ldots . . . . \\
\text { Zinc-cadmium-nitrate ......... }\end{array}$ & $\left|\begin{array}{c}1 \text { to } 5 \cdot 0 \\
25\end{array}\right|$ & $\begin{array}{c}\cdot 362 \text { to } \cdot 35 \overline{7} \\
-351\end{array}$ & $\begin{array}{l}357 \text { to } \cdot 367 \\
-357\end{array}$ & $\begin{array}{c}+.005 \text { to }-.010 \\
-.006\end{array}$ \\
\hline Zinc-cadmium-chloride $\ldots . .$. & 25 to 80 & 1) 330 to 262 & 366 to $\cdot 240$ & -036 to +045 \\
\hline $\begin{array}{l}\text { Zinc-cadmium-bromide } \ldots \ldots \\
\text { Zinc-cadmium-iodide }\end{array}$ & $\begin{array}{r}\cdot 25 \\
.25 \\
\end{array}$ & $\begin{array}{r}315 \\
.3 \% 0\end{array}$ & 338 & -023 \\
\hline Copper-cadmium-sulphate .... & 1 to $2 \cdot 0$ & 752 to $\cdot 755$ & $\begin{array}{c}279 \\
.743 \text { to }-748\end{array}$ & $\begin{array}{c}+\cdot 043 \\
+.009 \text { to }+.007\end{array}$ \\
\hline $\begin{array}{l}\text { Copper-cadmium-nitrate.... } \\
\text { Copper-cadmium-chloride. }\end{array}$ & 25 & 713 & 748 & -035 \\
\hline $\begin{array}{r}\mathrm{Cu}_{2} \mathrm{Cl}_{2} \text { in } \mathrm{CuCl}_{2} \text { sol., or } \\
\mathrm{CuCl}_{2} \text { sol. alone }\end{array}$ & $\cdot 25$ & $\cdot 769$ & & +.097 \\
\hline $\begin{array}{l}\text { Copper-cadmium-chloride. } \\
\mathrm{Cu}_{2} \mathrm{Cl}_{2} \text { in } \mathrm{CdCl}_{2} \text { solution. }\end{array}$ & .25 & 671 & 672 & -001 \\
\hline $\begin{array}{c}\text { Copper-cadmium-chloride. } \\
\mathrm{Cu}_{2} \mathrm{Cl}_{2} \text { in } \mathrm{ZnCl}_{2} \text { solution }\end{array}$ & .25 & 659 & & -013 \\
\hline $\begin{array}{l}\text { Zino-silver-chloride. } \\
\mathrm{AgOl} \text { in } \mathrm{CuCl}_{2} \text { solution ... }\end{array}$ & .25 & $1 \cdot 136$ & $1 \cdot 192$ & -.056 \\
\hline $\left.\begin{array}{l}\text { Zinc-silver-bromide } \\
\mathrm{AgBr} \text { in } \mathrm{ZnBr}_{2} \text { solution... }\end{array}\right\}$ & $\cdot 25$ & .906 & $1 \cdot 005$ & -.099 \\
\hline $\left.\begin{array}{l}\text { Zinc-silver-iodide. } \\
\mathrm{AgI} \text { in } \mathrm{ZnI}_{2} \text { solution ....... }\end{array}\right\}$ & $\cdot 25$ & $\cdot 7055$ & 726 & -0205 \\
\hline $\left.\begin{array}{c}\text { Cadmium-silver-chloride. } \\
\mathrm{AgCl} \text { in } \mathrm{CuCl}_{2} \text { sol. ......... }\end{array}\right\}$ & .25 & $\cdot 807$ & & $-\cdot 019$ \\
\hline $\left.\begin{array}{c}\text { Cadmium-silver-chloride. } \\
\mathrm{AgCl} \text { in } \mathrm{CdCl}_{22} \text { solution ... }\end{array}\right\}$ & $\cdot 25$ & 761 & .826 & -065 \\
\hline $\left.\begin{array}{c}\text { Cadmium-silver-chloride, } \\
\mathrm{AgOl} \text { in } \mathrm{ZnCl}_{2} \text { solution .... }\end{array}\right\}$ & $\cdot 25$ & 751 & & -.075 \\
\hline $\left.\begin{array}{c}\text { Cadmium-silver iodide. } \\
\mathrm{AgI} \text { in } \mathrm{ZnI}_{3} \text { solution ...... }\end{array}\right\}$ & .25 & 384 & $\cdot 447$ & -.063 \\
\hline 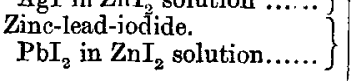 & $\cdot 25$ & $\cdot 455$ & $\cdot 457$ & -002 \\
\hline
\end{tabular}

